Original Article

\title{
Synergistic impact of $\alpha$-linolenic acid and $\alpha$-tocopherol on in vitro maturation and culture of buffalo oocytes
}

\author{
Impacto sinérgico do ácido $\alpha$-linolênico e $\alpha$-tocoferol na maturação in vitro e cultura \\ de oócitos de búfalo
}

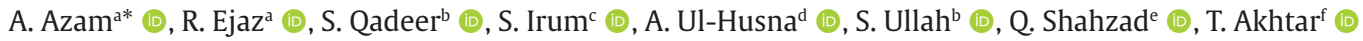 \\ and S. Akhter' (D) \\ aShaheed Benazir Bhutto Women University, Department of Zoology, Peshawar, Pakistan \\ bUniversity of Education, Division of Science \& Technology, Department of Zoology, Lahore, Pakistan \\ 'University of Gujrat, Department of Zoology, Gujrat, Pakistan \\ dUniversity of Haripur, Department of Zoology, Haripur, Pakistan \\ eBovine IVF Laboratory, Ovatech (Shandong) Biotechnology, Dongying, China \\ fBuffalo Research Institute Pattoki, Kasur, Lahore, Pakistan \\ gPir Mehr Ali Shah Arid Agriculture University, Department of Zoology, Rawalpindi, Pakistan
}

\begin{abstract}
The objective of the current study was to investigate the synergistic impact of $\alpha$-Tocopherol and $\alpha$-Linolenic acid $(100 \mu \mathrm{M})$ on IVM and IVC of Nili Ravi buffalo oocytes. Oocytes were obtained from the ovaries of slaughtered buffaloes within two hours after slaughter and brought to laboratory. Buffalo cumulus oocyte complexes were placed randomly in the five experimental groups included; GROUP 1: Maturation media (MM) + $100 \mu \mathrm{M}$ ALA

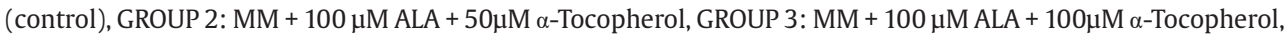
GROUP 4: MM + $100 \mu \mathrm{M}$ ALA + $200 \mu \mathrm{M} \alpha$-Tocopherol and GROUP 5: MM + $100 \mu \mathrm{M}$ ALA $+300 \mu \mathrm{M} \alpha$-Tocopherol under an atmosphere of $5 \% \mathrm{CO} 2$ in air at $38.5^{\circ} \mathrm{C}$ for $22-24 \mathrm{~h}$. Cumulus expansion and nuclear maturation status was determined (Experiment 1 ). In experiment 2, oocytes were matured as in experiment 1 . The matured oocytes were then fertilized in Tyrode's Albumin Lactate Pyruvate (TALP) medium for about $20 \mathrm{~h}$ and cultured in synthetic oviductal fluid (SOF) medium to determine effect of $\alpha$-Linolenic acid $(100 \mu \mathrm{M})$ and $\alpha$-Tocopherol in IVM medium on IVC of presumptive zygotes. To study the effect of $\alpha$-Linolenic acid $(100 \mu \mathrm{M})$ in IVM media and increasing concentration of $\alpha$-tocopherol in the culture media on early embryo development (Experiment 3 ), the presumptive zygotes were randomly distributed into the five experimental groups with increasing concentration of $\alpha$-tocopherol in culture media. Higher percentage of MII stage oocytes in experiment 1(65.2 \pm 2.0$)$, embryos at morula stage in experiment $2(30.4 \pm 1.5)$ and experiment $3(22.2 \pm 2.0)$ were obtained. However, overall results for cumulus cell expansion, maturation of oocyte to MII stage and subsequent embryo development among treatments remain statistically similar $(\mathrm{P}>0.05)$. Supplementation of $\alpha$-tocopherol in maturation media having $\alpha$-Linolenic acid and/ or in embryo culture media did not further enhance in vitro maturation of oocyte or embryo production.
\end{abstract}

Keywords: $\alpha$-linolenic acid, $\alpha$-tocopherol, buffalo, nuclear maturation, embryonic development.

\begin{abstract}
Resumo
O objetivo do presente estudo foi investigar o impacto sinérgico do $\alpha$-tocoferol e do ácido $\alpha$-linolênico (100 $\mu \mathrm{M})$ na MIV e CIV de oócitos de búfala Nili Ravi. Os oócitos foram obtidos dos ovários de búfalos abatidos duas horas após o abate e levados ao laboratório. Complexos de oócitos cumulus de búfalo foram colocados aleatoriamente nos cinco grupos experimentais incluídos; GRUPO 1: Meio de maturação (MM) + $100 \mu \mathrm{M}$ ALA (controle), GRUPO 2: MM + $100 \mu \mathrm{M}$ ALA $+50 \mu \mathrm{M} \alpha$-tocoferol, GRUPO 3: MM + $100 \mu \mathrm{M}$ ALA + $100 \mu \mathrm{M} \alpha$-tocoferol, GRUPO 4: MM + $100 \mu \mathrm{M}$ ALA + $200 \mu \mathrm{M} \alpha$-tocoferol e GRUPO 5: MM + $100 \mu \mathrm{M}$ ALA + $300 \mu \mathrm{M} \alpha$-tocoferol sob uma atmosfera de 5\% de $\mathrm{CO} 2 \mathrm{em}$ ar a $38,5^{\circ} \mathrm{C}$ por $22-24 \mathrm{~h}$. A expansão cumulus e o estado de maturação nuclear foram determinados (Experimento 1). No experimento 2, os oócitos foram maturados como no experimento 1. Os oócitos maturados foram então fertilizados em meio de Tyrode's Albumina Lactato Piruvato (TALP) por cerca de $20 \mathrm{~h}$ e cultivados em meio de fluido oviductal sintético (SOF) para determinar o efeito do ácido $\alpha$-linolênico (100 $\mu \mathrm{M})$ e $\alpha$-tocoferol em meio IVM em IVC de presumíveis zigotos. Para estudar o efeito do ácido $\alpha$-linolênico $(100 \mu \mathrm{M})$ em meio IVM e aumentar a concentração de $\alpha$-tocoferol no meio de cultura no desenvolvimento inicial do embrião (Experimento 3 ), os presumíveis zigotos foram distribuídos aleatoriamente nos cinco grupos experimentais com concentração crescente de $\alpha$-tocoferol em meios de cultura. Maior porcentagem de oócitos em estágio MII no experimento 1
\end{abstract}

*e-mail: asimaazam786@gmail.com

Received: June 23, 2021 - Accepted: August 25, 2021

This is an Open Access article distributed under the terms of the Creative Commons Attribution License, which permits unrestricted use, distribution, and reproduction in any medium, provided the original work is properly cited. 
$(65,2 \pm 2,0)$, embriões em estágio de mórula no experimento $2(30,4 \pm 1,5)$ e experimento $3(22,2 \pm 2,0)$ foram obtidos. No entanto, os resultados gerais para a expansão das células do cumulus, maturação do oócito para o estágio MII e desenvolvimento embrionário subsequente entre os tratamentos permanecem estatisticamente semelhantes $(\mathrm{P}>0,05)$. A suplementação de $\alpha$-tocoferol em meios de maturação com ácido $\alpha$-linolênico e / ou em meios de cultura de embriões não aumentou ainda mais a maturação in vitro de oócitos ou a produção de embriões.

Palavras-chave: ácido $\alpha$-linolênico, $\alpha$-tocoferol, búfalo, maturação nuclear, desenvolvimento embrionário.

\section{Introduction}

Dietary lipid supplementation is believed to enhance fertilizing potential in animals by increasing ovulatory follicle size, progesterone concentration in plasma and lifespan of corpus luteum (Sharma et al., 2020). Supplementing ruminants' diet with fats improves quality of the blastocysts obtained. Likewise, the in vitro bovine, ovine and porcine oocyte maturation and high quality embryos are obtained when fatty acids supplemented media was used (Marei et al., 2009; Ghaffarilaleh et al., 2014; Jeon et al ., 2020). We have previously shown that $\alpha$-linolenic acid $(100 \mu \mathrm{M})$ enriched in vitro growth media enhanced the rates of oocyte maturation and pre-implantation embryo development in Nili Ravi buffalo (Azam et al., 2017). Apart from the useful role of $\alpha$-linolenic acid, it is also susceptible to lipid peroxidation. As rising the fatty acids in media also increase the lipid droplets in oocyte which enhance lipid peroxidation in the cells (Halliwell and Chirico, 1993). Lipid peroxidation implicates production of reactive oxygen species that may obstruct oocyte quality for further development (Khalil et al., 2013).

The reactive oxygen species (ROS) like hydrogen peroxide, hydroxyl radicals and superoxide anions are produced naturally by developing embryos as they interact with their adjacent environment (Nasr-Esfahani and Johnson, 1991; Khurana and Niemann, 2000; Guerin et al., 2001). But complex nature of oviductal fluid i.e. hormones, defense agents, growth factors, glyco-proteins and antioxidants (Gandolfi et al., 1993; Bavister, 1995; Ozdaş et al., 2006; Aviles et al., 2010) ensures protection of embryos against oxidative stress and ROS (Guerin et al., 2001). Whereas, ROS are produced in an excess amount during in vitro culture of oocytes (Goto et al., 1993) and due to absence of counteract mechanism against oxidative stress the developing embryos are more liable to be harmed (Johnson and Nasr-Esfahani, 1994; Guerin et al., 2001) and are of low quality (Enright et al., 2000; Sadeesh et al., 2014).

To enhance quality of in vitro produced embryos, the supplementation of media with antioxidants is reported (Gordon, 1994; Lott et al., 2011). Alpha-tocopherol (Vitamin E) is an antioxidant that is reported to have efficient role not only in in vivo conditions but also positive effect during in vitro culture conditions (Miller et al., 1993; Olson and Seidel Junior, 2000) to protect the early embryo from free radicals (Wang et al., 2002). Vitamin E limits the damages to cell membranes (Niki et al., 1989; Van Metre and Callan, 2001), defends against lipid peroxidation (Wagner et al., 1996; Dalvit et al., 2005) and avoids apoptosis in mammalian cells (Carlson et al., 1993; Olson and Seidel Junior, 2000; Arias-Álvarez et al., 2018).

In our previous study (Azam et al., 2019) synthetic oviductal fluid medium co-cultured with monolayer of isologous oviductal epithelial cells further improved early embryo development. The putative mechanisms include detoxification and procurement of required metabolites and particular development stimulators into the surrounding medium (Malayer et al., 1988). Considering the role of $\alpha$-tocopherol (vitamin E) as cellular control of lipid peroxidation and as an antioxidant, it was assumed that addition of $\alpha$-tocopherol in the primary media with $\alpha$-linolenic acid $(100 \mu \mathrm{M})$ and culture media will further enhance in vitro growth and/or early embryonic maturation in buffalo. The intent was to examine the synergistic influence of increasing $\alpha$-tocopherol $(0 \mu \mathrm{M}$ (control), $50 \mu \mathrm{M}$, $100 \mu \mathrm{M}, 200 \mu \mathrm{M}$ and $300 \mu \mathrm{M}$ ) in IVC and IVM medium on oocyte maturation and/or embryos development.

\section{Materials and Methods}

\subsection{Collection of ovaries}

A total of 2250 buffalo ovaries were collected at a local abattoir immediately after slaughter and transported back to the laboratory in a thermos flask containing sterilized pre warmed phosphate buffered saline (PBS) maintained at $33-35^{\circ} \mathrm{C}$ within two hours after slaughter. After arrival in the laboratory, ovaries were rinsed with fresh PBS immediately.

\subsection{Collection and classification of cumulus oocyte complexes (COCS)}

Cumulus oocyte complexes (COCs) were collected by aspiration of 2-8 $\mathrm{mm}$ visible follicles present on the surface of ovaries as described earlier (Azam et al., 2017). The COCs were classified as grade A, B, C and D, based on cumulus mass investment and ooplasm homogeneity under stereomicroscope as described earlier (Azam et al., 2017). Only grade A and B oocytes were processed for IVM. A total of 1992 cumulus oocyte complexes (COCs) of grade $\mathrm{A}$ and $\mathrm{B}$ were collected.

\subsection{In vitro maturation (IVM)}

Selected oocytes were washed twice in PBS $\left(37^{\circ} \mathrm{C}\right)$ and twice in pre-equilibrated maturation medium. The washed oocytes were allocated into $100 \mu$ of respective culture droplets of each treatment group covered with sterile mineral oil (Sigma M8410) and matured in vitro in a water-jacketed incubator at $38.5^{\circ} \mathrm{C}$ under an atmosphere of $5 \% \mathrm{CO}_{2}$ in air with $95 \%$ humidity for $24 \mathrm{~h}$. All the media and culture dishes were equilibrated at $37{ }^{\circ} \mathrm{C}$ for at least 1-2 hours before experiment. Cumulus expansion was assessed by visual assessment using stereomicroscope as 1) not expanded, 2) partially expanded or 3) fully expanded. For determination of nuclear maturation stage, COCs were 
completely denuded, stained with $1 \%$ aceto-orcein and examined for metaphase II (MII) stage (Azam et al., 2017).

\subsection{In vitro fertilization (IVF)}

Three $0.5 \mathrm{~mL}$ straws of cryopreserved buffalo semen were thawed in water at $37{ }^{\circ} \mathrm{C}$ for 30 seconds. Thawed semen was placed in a $15 \mathrm{~mL}$ conical tube. Spermatozoa with maximum motility were collected by swim up technique (Parrish et al., 1986). About $250 \mu \mathrm{L}$ of thawed semen was deposited at the bottom of four $15 \mathrm{~mL}$ tubes containing $3 \mathrm{~mL}$ of pre warmed sperm wash medium (TALP: modified calcium-free Tyrode's Albumin Lactate Pyruvate with $6 \mathrm{mg} / \mathrm{mL}$ BSA fraction-V). Tubes were incubated at $45^{\circ}$ angle for 30 minutes. Supernatant from each tube was removed and transferred into another $15 \mathrm{~mL}$ conical tube and centrifuged at $1600 \mathrm{rpm}$ for 10 minutes. The pellet obtained after centrifugation was resuspended in prewarmed fertilization TALP supplemented with $0.1 \mathrm{mM}$ hypotaurine, $0.2 \mathrm{mM}$ penicillamine, $0.01 \mathrm{mM}$ epinephrine, $10 \mu \mathrm{g} / \mathrm{mL}$ heparin, to get a final concentration of $2 \times 10^{6}$ live sperm $\mathrm{mL}^{-1}$. After 24 hours of IVM, buffalo oocytes were washed in fertilization media and were placed in fertilization droplet ( $5 \mathrm{COCs} / 50 \mu \mathrm{L}$ droplet) of pre warmed fertilization medium under mineral oil with final sperm concentration of $2 \times 10^{6} \mathrm{~mL}^{-1}$. The oocyte and spermatozoa were incubated at $38.5{ }^{\circ} \mathrm{C}$ under $5 \% \mathrm{CO} 2$ with maximum humidity for $20 \mathrm{~h}$ (Azam et al., 2019).

\subsection{In vitro embryo culture (IVC)}

After IVF, presumptive zygotes were denuded by vortexing in PBS. After one washing with PBS and two with culture media; synthetic oviductal fluid medium (SOF), presumptive zygotes were transferred to $50 \mu \mathrm{L}$ of culture drop with isologous oviductal cell monolayer and cultured in an incubator at $38.5^{\circ} \mathrm{C}, 5 \% \mathrm{CO}_{2}$ and $95 \%$ humidity. On day 2 of development (Day 0 = day of insemination) the cleavage rate (number of oocytes cleaved/total $\times 100$ COCs incubated) was observed, After three days of culture $40 \mu \mathrm{L}$ of culture medium was replaced without disrupting the monolayer. Further developmental stages were evaluated and recorded every other day (Azam et al., 2019).

\subsection{Experimental design}

\subsubsection{Experiment 1: effect of $\alpha$-linolenic acid and $\alpha$-tocopherol in maturation media on IVM of buffalo oocytes}

A total of 662 cumulus oocyte complexes (COCs) of grade $A$ and $B$, were collected by aspiration of $2-8 \mathrm{~mm}$ visible follicles present on the surface of 750 ovaries and processed for IVM. The $\alpha$-Linolenic acid level that yielded best results in terms of oocyte maturation and early embryo development in our previous study (Azam et al., 2019) was used in this experiment. COCs were placed randomly in the five experimental groups included; GROUP 1: TCM-199 + $100 \mu \mathrm{M}$ ALA (control), GROUP 2: $\mathrm{MM}+100 \mu \mathrm{M}$ ALA $+50 \mu \mathrm{M} \alpha$-Tocopherol, GROUP 3: MM

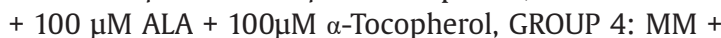
$100 \mu \mathrm{M}$ ALA + $200 \mu \mathrm{M} \alpha$-Tocopherol and GROUP 5: MM +
$100 \mu \mathrm{M}$ ALA $+300 \mu \mathrm{M} \alpha$-Tocopherol. Results of expansion of cumulus cells and nuclear maturation status of COCs after 24 hours of maturation, from six replicates were pooled in this experiment.

\subsubsection{Experiment 2: effect of $\alpha$-linolenic acid and $\alpha$-tocopherol in maturation media on early embryo development in buffalo oocytes}

A total of 560 cumulus oocyte complexes (COCs) of grade $A$ and $B$, were collected by aspiration of $2-8 \mathrm{~mm}$ visible follicles present on the surface of 700 ovaries and processed for IVM. All the treatment groups of maturation media were same as experiment 1 . After $24 \mathrm{~h}$ of maturation oocytes were inseminated with prepared sperm for in vitro fertilization and were incubated for $20 \mathrm{~h}$. After fertilization presumptive zygotes were processed for in vitro culture. On day 2 of development (Day 0 = day of insemination) the cleavage rate (number of oocytes cleaved/total $\times 100$ COCs incubated) was observed. Further developmental stages were evaluated and recorded every other day. Results of early embryo development from five replicates were pooled in this experiment.

\subsubsection{Experiment 3: effect of $\alpha$-linolenic acid (ALA) in IVM} media and $\alpha$-tocopherol in culture media on subsequent embryo development

A total of 770 cumulus oocyte complexes (COCs) of grade $A$ and $B$, were collected by aspiration of $2-8 \mathrm{~mm}$ visible follicles present on the surface of 850 ovaries and processed for IVM. Oocytes were allocated to IVM medium supplemented with $\alpha$-Linolenic acid $(100 \mu \mathrm{M})$. After fertilization presumptive zygotes were placed randomly in the five experimental groups with increasing concentration of $\alpha$-tocopherol in culture media $(0 \mu \mathrm{M}$ (control), $50 \mu \mathrm{M}$, $100 \mu \mathrm{M}, 200 \mu \mathrm{M}$ and $300 \mu \mathrm{M} \alpha$-Tocopherol). Results of early embryo development from five replicates were pooled in this experiment.

\subsection{Statistical analysis}

Data of cumulus expansion, nuclear maturation stages of in vitro matured oocytes, and subsequent developmental stages were recorded and analyzed by one-way analysis of variance (ANOVA) at $5 \%$ level of significance.

\section{Results}

\subsection{Experiment 1: effect of $\alpha$-linolenic acid and $\alpha$-tocopherol} in maturation media on IVM of buffalo oocytes

The data on the degree of cumulus expansion and nuclear maturation of buffalo COCs matured in the in vitro maturation media supplemented with $100 \mu \mathrm{M}$ ALA and different concentrations of $\alpha$-tocopherol are shown in Figure 1 and Table 1 respectively. Supplementation of different concentrations of $\alpha$-tocopherol ( 0 (control), 50 , 100,200 and $300 \mu \mathrm{M}$ ) in the maturation media having $100 \mu \mathrm{M}$ ALA did not differ $(\mathrm{P}>0.05)$ in degree of cumulus expansion and nuclear maturation rate of buffalo oocytes as compared to control. 


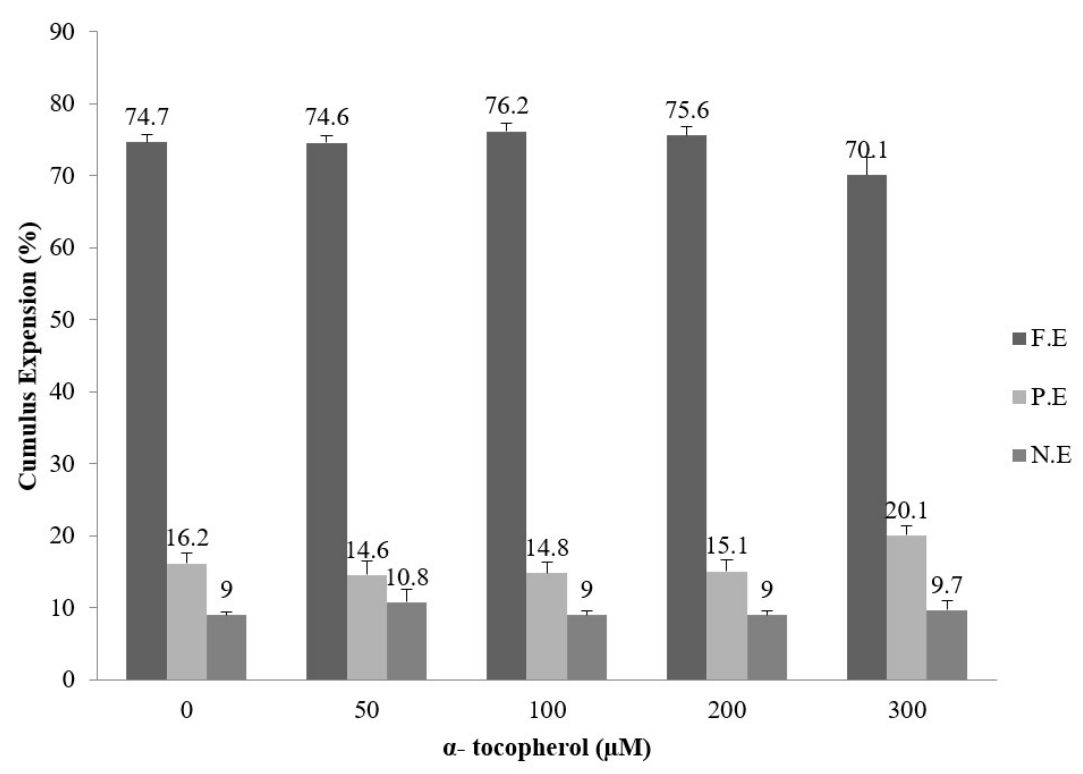

Figure 1. Cumulus expansion rate of buffalo oocytes after 24 hours of maturation in IVM medium supplemented with ALA (100 $\mu M)$ and different concentrations of $\alpha$-tocopherol. Data were collected in six independent repeats. All the values were statistically non-significant among treatments $(P>0.05)$. F.E: Fully Expanded; P.E: Partially Expanded; N.E: Not Expanded

Table 1. Nuclear maturation status of buffalo oocytes after 24 hours of maturation in IVM medium supplemented with ALA (100 $\mu M$ ) and different concentrations of $\alpha$-tocopherol.

\begin{tabular}{|c|c|c|c|c|c|}
\hline \multirow{2}{*}{$\begin{array}{c}\text { Treatments } \\
\text { ALA }+\alpha-\text {-tocopherol }\end{array}$} & \multirow{2}{*}{ No. of COCs } & \multicolumn{4}{|c|}{ Nuclear Maturation Status (Mean percentage \pm SEM) } \\
\hline & & GV N (\% & GVBD N (\% \pm SEM) & MI N (\% & MII N (\%さSEM) \\
\hline $100 \mu \mathrm{M}+0 \mu \mathrm{M}$ & 154 & $2(1.3 \pm 1.4)$ & $34(22.1 \pm 1.0)$ & $24(15.6 \pm 1.8)$ & $94(61.0 \pm 1.7)$ \\
\hline $100 \mu \mathrm{M}+50 \mu \mathrm{M}$ & 130 & $0(0.0 \pm 0.0)$ & $28(21.5 \pm 1.0)$ & $22(16.9 \pm 1.2)$ & $80(61.5 \pm 0.6)$ \\
\hline $100 \mu \mathrm{M}+100 \mu \mathrm{M}$ & 122 & $2(1.6 \pm 1.2)$ & $26(21.3 \pm 0.9)$ & $16(13.1 \pm 1.6)$ & $78(63.9 \pm 2.3)$ \\
\hline $100 \mu \mathrm{M}+200 \mu \mathrm{M}$ & 132 & $2(1.5 \pm 1.1)$ & $28(21.2 \pm 1.8)$ & $16(12.1 \pm 1.4)$ & $86(65.2 \pm 2.0)$ \\
\hline $100 \mu \mathrm{M}+300 \mu \mathrm{M}$ & 124 & $2(1.6 \pm 1.12$ & $28(22.6 \pm 1.9)$ & $20(16.1 \pm 2.3)$ & $74(59.7 \pm 0.9)$ \\
\hline
\end{tabular}

Data were collected in six independent repeats. All the values were statistically non-significant $(P>0.05)$ among treatments. GV: Germinal Vesicle; GVBD: Germinal Vesicle Breakdown; MI: Metaphase I; MII: Metaphase II; N: Total number of COCs.

\subsection{Experiment 2: effect of $\alpha$-linolenic acid and} $\alpha$-tocopherol in maturation media on early embryo development in buffalo oocytes

The data on effect of supplementation of ALA $(100 \mu \mathrm{M})$ combined with different concentrations of $\alpha$-tocopherol in the in vitro maturation medium on cleavage rate and embryonic development stage are shown in Table 2. The cleavage rate, development of embryo up to 4-8 cell stage, $>8$ cell stage and morula did not vary $(P>0.05)$ when oocytes were matured in the in vitro maturation media supplemented with $100 \mu \mathrm{M}$ ALA combined with $\alpha$-tocopherol at 0 (control), 50, 100, 200 and $300 \mu \mathrm{M}$.

\subsection{Experiment 3: effect of $\alpha$-linolenic acid ( $A L A)$ in IVM} media and $\alpha$-tocopherol in culture media on subsequent embryo development

The data on the effect of supplementing ALA $(100 \mu \mathrm{M})$ in the in vitro maturation medium and different concentrations of $\alpha$-tocopherol ( 0 (control), 50, 100, 200 and
$300 \mu \mathrm{M})$ in the in vitro culture media on cleavage rate and developmental stages of buffalo embryos are shown in Table 3. Results indicate that values for cleavage rate and embryonic development up to $4-8$ cell stage, $>8$ cell stage and morula did not vary when the in vitro culture media was supplemented with $\alpha$-Tocopherol at 0 (control), 50, 100,200 and $300 \mu \mathrm{M}$.

\section{Discussion}

Dietary source of fatty acids have been reported to affect composition of fatty acids in the follicular fluid that in turn influences molecular mechanisms in the oocyte and mitochondrial distribution and activity (Marei et al., 2010). Provision of fatty acids in the in vitro maturation media provides energy source to the maturing oocytes (Sturmey et al., 2009), control MAPK signaling pathway and are a direct source of prostaglandins (PGs). PGE $_{2}$ serves as a mediator of oocyte maturation and results in increased 


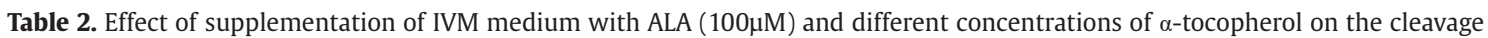
rate and subsequent developmental of buffalo oocytes in vitro.

\begin{tabular}{|c|c|c|c|c|c|}
\hline \multirow{2}{*}{$\begin{array}{l}\text { Treatments } \\
\text { ALA+ } \alpha- \\
\text { tocopherol in } \\
\text { IVM Medium }\end{array}$} & \multirow[b]{2}{*}{ No. of COCs } & \multicolumn{4}{|c|}{ Developmental stages (Mean percentage \pm SEM) } \\
\hline & & $\begin{array}{c}\text { Cleavage } \\
\text { N (\%+SEM) }\end{array}$ & $\begin{array}{c}\text { 4-8 cell embryos } \\
\mathrm{N}(\% \pm \mathrm{SEM})\end{array}$ & $\begin{array}{c}>8 \text { cell embryos } \\
N(\% \pm S E M)\end{array}$ & $\begin{array}{c}\text { Morulla } \\
\text { N (\% } \$ \text { SEM) }\end{array}$ \\
\hline $100 \mu \mathrm{M}+0 \mu \mathrm{M}$ & 112 & $66(58.9 \pm 2.7)$ & $52(46.4 \pm 3.5)$ & $40(35.7 \pm 2.2)$ & $26(23.2 \pm 2.3)$ \\
\hline $100 \mu \mathrm{M}+50 \mu \mathrm{M}$ & 112 & $66(58.9 \pm 2.7)$ & $50(44.6 \pm 2.2)$ & $40(35.7 \pm 2.2)$ & $26(23.2 \pm 1.2)$ \\
\hline $100 \mu \mathrm{M}+100 \mu \mathrm{M}$ & 112 & $68(60.7 \pm 2.3)$ & $52(46.4 \pm 3.8)$ & $40(35.7 \pm 4.4)$ & $28(25.0 \pm 3.1)$ \\
\hline $100 \mu \mathrm{M}+200 \mu \mathrm{M}$ & 112 & $72(64.3 \pm 5.6)$ & $54(48.2 \pm 3.1)$ & $42(37.5 \pm 1.8)$ & $34(30.4 \pm 1.5)$ \\
\hline $100 \mu \mathrm{M}+300 \mu \mathrm{M}$ & 112 & $68(60.7 \pm 5.0)$ & $52(46.4 \pm 3.8)$ & $42(37.5 \pm 1.8)$ & $28(25.0 \pm 3.1)$ \\
\hline
\end{tabular}

Data were collected in five independent repeats. All the values were statistically non-significant $(P>0.05)$ among treatments.

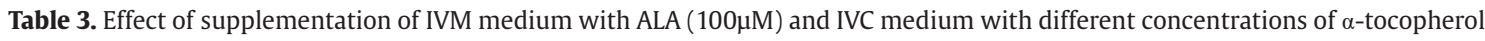
on cleavage rate and subsequent embryonic development of buffalo oocytes in vitro.

\begin{tabular}{|c|c|c|c|c|c|}
\hline \multirow{2}{*}{$\begin{array}{l}\text { Treatments } \\
\text { ALA in IVM } \\
+\alpha \text {-tocopherol } \\
\text { in IVC }\end{array}$} & \multirow[b]{2}{*}{ No. of COCs } & \multicolumn{4}{|c|}{ Developmental stages (Mean percentage \pm SEM) } \\
\hline & & $\begin{array}{c}\text { Cleavage } \\
\mathbf{N}(\% \pm \text { SEM) }\end{array}$ & $\begin{array}{c}\text { 4-8 cell embryos } \\
N \text { (\% } \% \text { SEM) }\end{array}$ & $\begin{array}{c}>8 \text { cell embryos } \\
N(\% \pm S E M)\end{array}$ & $\begin{array}{c}\text { Morula } \\
\text { N (\% } \pm \text { SEM) }\end{array}$ \\
\hline $100 \mu \mathrm{M}+0 \mu \mathrm{M}$ & 154 & $86(55.9 \pm 1.6)$ & $60(39.1 \pm 2.2)$ & $48(31.3 \pm 1.8)$ & $26(17.0 \pm 1.7)$ \\
\hline $100 \mu \mathrm{M}+50 \mu \mathrm{M}$ & 154 & $88(57.3 \pm 2.7)$ & $64(41.4 \pm 2.5)$ & $46(29.8 \pm 2.2)$ & $26(17.0 \pm 1.7)$ \\
\hline $100 \mu \mathrm{M}+100 \mu \mathrm{M}$ & 154 & $94(61.0 \pm 1.9)$ & $66(42.9 \pm 1.5)$ & $50(32.6 \pm 2.2)$ & $28(18.5 \pm 3.0)$ \\
\hline $100 \mu \mathrm{M}+200 \mu \mathrm{M}$ & 154 & $96(62.3 \pm 3.8)$ & $72(46.8 \pm 1.4)$ & $54(35.1 \pm 1.2)$ & $34(22.2 \pm 2.0)$ \\
\hline $100 \mu \mathrm{M}+300 \mu \mathrm{M}$ & 154 & $92(59.7 \pm 4.0)$ & $66(42.9 \pm 1.5)$ & $46(29.9 \pm 1.4)$ & $24(15.6 \pm 1.6)$ \\
\hline
\end{tabular}

Data were collected in five independent repeats. All the values were statistically non-significant among treatments $(\mathrm{P}>0.05)$.

MII stage oocytes and better quality embryos (Marei et al., 2009). However, in addition to valuable role of fatty acids for in vitro maturation of oocytes and embryo production, lipid peroxidation of fatty acids is unavoidable that may induce oxidative stress. In order to overcome the oxidative stress, different antioxidants have been studied such as vitamins $(A, C, E)$, hypotaurine, taurine and cysteamine (Guerin et al., 2001; Thiyagarajan and Valivittan, 2009), with varying effects on in vitro maturation and embryo development.

Use of $\alpha$-tocopherol with ALA in IVM medium has not been reported previously. In present study, the addition of $\alpha$-tocopherol in maturation medium along with ALA $(100 \mu \mathrm{M})$ did not improve the efficiency of the medium for expansion of cumulus mass and rate of nuclear maturation in buffalo oocytes in vitro. Perhaps the concentration of ALA used in this study has not produced oxidative stress to a level that could have been compensated by the antioxidant. As, mentioned earlier (Azam et al., 2017), ALA at higher concentration $(300 \mu \mathrm{M})$ reduced the number of COCs with fully expanded oocytes and the rate of oocytes reaching up to MII stage. This reduced oocyte maturation rate at higher concentration of ALA, might have been due to the production of ROS in the IVM medium. Another plausible reason might be that the selected cumulus oocyte complexes were good enough that they have protected oocytes from oxidative stress. Earlier studies suggested that composition of culture medium and quality of oocyte especially presence of cumulus cells around oocytes play important role for protecting oocytes against oxidative stress (Thiyagarajan and Valivittan, 2009). These cumulus cells around the oocytes protect oocytes from changes in the intracellular environment caused by changes in the extracellular medium (Ali et al., 2003). Moreover, previous studies on cattle (Dalvit et al., 2005) and buffalo (Thiyagarajan and Valivittan, 2009), demonstrated that $\alpha$-tocopherol alone in IVM medium failed to affect oocyte maturation rates, suggesting that the antioxidant have no direct effect on nuclear and/or cytoplasmic maturation.

During in vitro culture conditions for early embryos, increased generation of reactive oxygen species (ROS) leads to lipid peroxidation of cellular membranes (Johnson and Nasr-Esfahani, 1994) that may lead to impairment in the permeability and function of membranes, ultimately causing permanent cell damage (Olson and Seidel Junior, 2000). Pre-compaction embryos have less complex system development as compared to post-compaction embryos; therefore they are more liable to oxidative damage (Lane and Gardner, 2007). Reducing oxygen concentration in the in vitro culture environment enhanced the embryo development in mouse (Pabon Junior et al., 1989). Similarly, supplementing antioxidants in culture media also improved the efficiency of culture media for bovines (Marei et al., 2010; Khalil et al., 2013).

Alpha-tocopherol protects mammalian cells against lipid peroxidation (Chow, 1991) and when supplemented 
in culture media is reported to increase the survival rates of embryos (Steele et al., 1974). However, results in present study demonstrated that $\alpha$-tocopherol addition in the culture medium was not efficient to improve the development rate of buffalo embryos at any stage of in vitro culture. In earlier studies positive effects of $\alpha$-tocopherol on embryo development have been reported in buffalo (Thiyagarajan and Valivittan, 2009) and cattle (Olson and Seidel Junior, 2000) during IVC. Although mammalian gametes and embryos seem capable to accept $\alpha$-tocopherol, the culture environment in which it is used (i.e., co-culture with oviductal cells) is possibly responsible for its efficacy. In the present study, the use of co-culture (oviduct epithelial cell) might have helped reduced $\mathrm{O}_{2}$ concentration in culture media and detoxified diffusible ROS by antioxidant systems present in these cells (Ouhibi et al., 1989; El-Mouatassim et al., 2000) to an extent that $\alpha$-tocopherol have not shown its effect. Another possible reason might be the high number of oviductal cells used in culture media that may have consumed $\alpha$-tocopherol, thereby reducing the effect of $\alpha$-tocopherol on the embryos.

\section{Conclusion}

It is concluded from this study that supplementation of $\alpha$-tocopherol in the basic media with $\alpha$-linolenic acid $(100 \mu \mathrm{M})$ and culture media with isologous oviductal epithelial cells did not improve the in vitro maturation and/or early embryonic development of buffalo oocytes.

\section{Acknowledgements}

Authors are thankful to Buffalo Research Institute (BRI), Pattoki, Pakistan, for assistance throughout the experimental period. The authors are also thankful to Higher Education Commission, Pakistan, for financial support.

\section{References}

ALI, A.A., BILODEAU, J.F. and SIRARD, M.A., 2003. Antioxidant requirements for bovine oocytes varies during in vitro maturation, fertilization and development. Theriogenology, vol. 59, no. 3-4, pp. 939-949. http://dx.doi.org/10.1016/S0093691X(02)01125-1. PMid:12517395.

ARIAS-ÁLVAREZ, M., GARCÍA-GARCÍA, R.M., LÓPEZ-TELLO, J., REBOLLAR, P.G., GUTIÉRREZ-ADÁN, A. and LORENZO, P.L., 2018. $\alpha$-Tocopherol modifies the expression of genes related to oxidative stress and apoptosis during in vitro maturation and enhances the developmental competence of rabbit oocytes. Reproduction, Fertility, and Development, vol. 30, no. 12, pp. 1728-1738. http://dx.doi.org/10.1071/RD17525. PMid:29966585.

AVILÉS, M., GUTIÉRREZ-ADÁN, A. and COY, P., 2010. Oviductal secretions: will they be key factors for the future ARTs? Molecular Human Reproduction, vol. 16, no. 12, pp. 896-906. http://dx.doi. org/10.1093/molehr/gaq056. PMid:20584881.

AZAM, A., HUSNA, A., QADEER, S., SHAHZAD, Q., EJAZ, R., ULLAH, N., AKHTAR, T. and AKHTER, S., 2019. Synthetic oviductal fluid medium with isologous oviductal epithelial cells improves the development of in vitro produced Nili Ravi buffalo
(Bubalus bubalis) embryos. Pakistan Journal of Zoology, vol. 51, no. 6, pp. 2007-2014. http://dx.doi.org/10.17582/journal. pjz/2019.51.6.2007.2014.

AZAM, A., SHAHZAD, Q., UL-HUSNA, A., QADEER, S., EJAZ, R., FOULADI-NASHTA, A.A., KHALID, M., ULLAH, N., AKHTAR, T. and AKHTER, S., 2017. Supplementing $\alpha$-Linolenic acid in the in vitro maturation media improves nuclear maturation rate of oocytes and early embryonic development in the Nili Ravi buffalo. Animal Reproduction, vol. 14, no. 4, pp. 1161-1169. http://dx.doi.org/10.21451/1984-3143-AR859.

BAVISTER, B.D., 1995. Culture of preimplantation embryos: facts and artifacts. Human Reproduction Update, vol. 1, no. 2, pp. 91148. http://dx.doi.org/10.1093/humupd/1.2.91. PMid:15726768.

CARLSON, J.C., WU, X.M. and SAWADA, M., 1993. Oxygen radicals and the control of ovarian corpus luteum function. Free Radical Biology E' Medicine, vol. 14, no. 1, pp. 79-84. http://dx.doi. org/10.1016/0891-5849(93)90511-R. PMid:8454226.

CHOW, C.K., 1991. Vitamin E and oxidative stress. Free Radical Biology \& Medicine, vol. 11, no. 2, pp. 215-232. http://dx.doi. org/10.1016/0891-5849(91)90174-2. PMid:1937140.

DALVIT, G., LLANES, S.P., DESCALZO, A., INSANI, M., BECONI, M. and CETICA, P., 2005. Effect of alpha-tocopherol and ascorbic acid on bovine oocyte in vitro maturation. Reproduction in Domestic Animals, vol. 40, no. 2, pp. 93-97. http://dx.doi.org/10.1111/j.14390531.2004.00522.x. PMid:15819954.

EL-MOUATASSIM, S., GUÉRIN, P. and MÉNÉZO, Y., 2000. Mammalian oviduct and protection against free oxygen radicals: expression of genes encoding antioxidant enzymes in human and mouse. European Journal of Obstetrics, Gynecology, and Reproductive Biology, vol. 89, no. 1, pp.1-6. http://dx.doi.org/10.1016/S03012115(99)00169-4. PMid:10733016.

ENRIGHT, B.P., LONERGAN, P., DINNYES, A., FAIR, T., WARD, F.A., YANG, X. and BOLAND, M.P., 2000. Culture of in vitro produced bovine zygotes in vitro vs in vivo: implications for early embryo development and quality. Theriogenology, vol. 54, no. 5, pp. 659-673. http://dx.doi.org/10.1016/S0093-691X(00)00381-2. PMid: 11101029 .

GANDOLFI, F., PASSONI, L., MODINA, S., BREVINI, T.A., VARGA, Z. and LAURIA, A., 1993. Similarity of an oviduct-specific glycoprotein between different species. Reproduction, Fertility, and Development, vol. 5, no. 4, pp. 433-443. http://dx.doi. org/10.1071/RD9930433. PMid:8153393.

GHAFFARILALEH, V., FOULADI-NASHTA, A. and PARAMIO, M.T., 2014. Effect of $\alpha$-linolenic acid on oocyte maturation and embryo development of prepubertal sheep oocytes. Theriogenology, vol. 82, no. 5, pp. 686-696. http://dx.doi.org/10.1016/j. theriogenology.2014.05.027. PMid:25015785.

GORDON, I.,, 1994. Laboratory production of cattle embryos. London: Cambridge University Press. https://doi. org/10.1079/9780851996660.0000.

GOTO, Y., NODA, Y., MORI, T. and NAKANO, M., 1993. Increased generation of reactive oxygen species in embryos cultured in vitro. Free Radical Biology \& Medicine, vol. 15, no. 1, pp. 69-75. http://dx.doi.org/10.1016/0891-5849(93)90126-F. PMid:8359711.

GUÉRIN, P., EL-MOUATASSIM, S. and MENEZO, Y., 2001. Oxidative stress and protection against reactive oxygen species in the pre-implantation embryo and its surroundings. Human Reproduction Update, vol. 7, no. 2, pp. 175-189. http://dx.doi. org/10.1093/humupd/7.2.175. PMid:11284661.

HALLIWELL, B. and CHIRICO, S., 1993. Lipid peroxidation: its mechanism, measurement, and significance. The American Journal of Clinical Nutrition, vol. 57, no. 5, suppl., pp. 715S-725S. http://dx.doi.org/10.1093/ajcn/57.5.715S. PMid:8475889. 
JEON, Y.E., HWANGBO, Y., KIM, S.Y. and PARK, C.K., 2020. Alphalinolenic acid enhances maturation and developmental competence via regulation of glutathione, cAMP and fatty acid accumulation during in vitro maturation of porcine oocytes. Journal of Animal Reproduction and Biotechnology, vol. 35, no. 4, pp. 357-365. http://dx.doi.org/10.12750/JARB.35.4.357.

JOHNSON, M.H. and NASRESFAHANI, M.H., 1994. Radical solutions and cultural problems: could free oxygen radicals be responsible for the impaired development of preimplantation mammalian embryos in vitro? BioEssays, vol. 16, no. 1, pp. 31-38. http:// dx.doi.org/10.1002/bies.950160105. PMid:8141805.

KHALIL, W.A., MAREI, W.F. and KHALID, M., 2013. Protective effects of antioxidants on linoleic acid-treated bovine oocytes during maturation and subsequent embryo development. Theriogenology, vol. 80, no. 2, pp. 161-168. http://dx.doi. org/10.1016/j.theriogenology.2013.04.008. PMid:23683689.

KHURANA, N.K. and NIEMANN, H., 2000. Energy metabolism in preimplantation bovine embryos derived in vitro or in vivo. Biology of Reproduction, vol. 62, no. 4, pp. 847-856. http://dx.doi. org/10.1095/biolreprod62.4.847. PMid:10727252.

LANE, M. and GARDNER, D.K., 2007. Embryo culture medium: which is the best? Best Practice $\mathcal{E}$ Research. Clinical Obstetrics $\mathcal{E}$ Gynaecology, vol.21, no. 1, pp. 83-100. http://dx.doi.org/10.1016/j. bpobgyn.2006.09.009. PMid:17090393.

LOTT, W.M., ANCHAMPARUTHY, V.M., MCGILLIARD, M.L., MULLARKY, I.K. and GWAZDAUSKAS, F.C., 2011. Influence of cysteine in conjunction with growth factors on the development of in vitroproduced bovine embryos. Reproduction in Domestic Animals, vol. 46, no. 4, pp. 585-594. http://dx.doi.org/10.1111/j.14390531.2010.01706.x. PMid:20946545.

MALAYER, J.R., HANSEN, P.J. and BUHI, W.C., 1988. Secretion of proteins by cultured bovine oviducts collected from estrus through early diestrus. Journal of Experimental Zoology, vol. 248, no. 3, pp. 345-353. https://doi.org/10.1002/ jez.1402480313.

MAREI, W.F., WATHES, D.C. and FOULADI-NASHTA, A.A., 2009. The effect of linolenic acid on bovine oocyte maturation and development. Biology of Reproduction, vol. 81, no. 6, pp. 1064-1072. http://dx.doi.org/10.1095/biolreprod.109.076851. PMid: 19587335.

MAREI, W.F., WATHES, D.C. and FOULADI-NASHTA, A.A., 2010. Impact of linoleic acid on bovine oocyte maturation and embryo development. Reproduction, vol. 139, no. 6, pp. 979-988. http:// dx.doi.org/10.1530/REP-09-0503. PMid:20215338.

MILLER, W.R., BENEFIELD, R.G. and TONIGAN, J.S., 1993. Enhancing motivation for change in problem drinking: a controlled comparison of two therapist styles. Journal of Consulting and Clinical Psychology, vol. 61, no. 3, pp. 455-461. http://dx.doi. org/10.1037/0022-006X.61.3.455. PMid:8326047.

NASR-ESFAHANI, M.M. and JOHNSON, M.H., 1991. The origin of reactive oxygen species in mouse embryos cultured in vitro. Development, vol. 113, no. 2, pp. 551-560. http://dx.doi. org/10.1242/dev.113.2.551. PMid:1664322.

NIKI, E., YAMAMOTO, Y., TAKAHASHI, M., KOMURO, E. and MIYAMA, Y., 1989. Inhibition of oxidation of biomembranes by tocopheror. Annals of the New York Academy of Sciences, vol. 570, no. 1, pp. 23-31. http://dx.doi.org/10.1111/j.1749-6632.1989.tb14905.x. PMid:2698105.

OLSON, S.E. and SEIDEL JUNIOR, G.E., 2000. Culture of in vitro-produced bovine embryos with vitamin $\mathrm{E}$ improves development in vitro and after transfer to recipients. Biology of Reproduction, vol. 62, no. 2, pp. 248-252. http://dx.doi. org/10.1095/biolreprod62.2.248. PMid:10642559.

OUHIBI, N., MENEZO, Y., BENET, G. and NICOLLET, B., 1989. Culture of epithelial cells derived from the oviduct of different species. Human Reproduction, vol. 4, no. 3, pp. 229-235. http://dx.doi. org/10.1093/oxfordjournals.humrep.a136877. PMid:2715297.

OZDAŞ, O.B., PABUCCUOGLU, S. and ÝLERI, Ý.K., 2006. Effects of monopotassium phosphate and oviduct cells on the in vitro fertilized mice embryos development. Medycyna Weterynaryjna, vol. 62, no. 3, pp. 281-284.

PABON JUNIOR, J.E., FINDLEY, W.E. and GIBBONS, W.E., 1989. The toxic effect of short exposures to the atmospheric oxygen concentration on early mouse embryonic development. Fertility and Sterility, vol.51, no. 5, pp. 896-900. http://dx.doi.org/10.1016/ S0015-0282(16)60688-X. PMid:2707466.

PARRISH, J.J., SUSKO-PARRISH, J.L., LEIBFREID-RUTLEDGE, M.L., CRISTER, E.S., EYSTONE, W.H. and FIRST, N., 1986. Bovine in vitro fertilization with frozenthawed semen. Theriogenology, vol. 25, no. 4, pp. 591-600. https://doi.org/10.1016/0093691X(86)90143-3.

SADEESH, E.M., SHAH, F., BALHARA, A.K., THIRUMARAN, S.M., YADAV, S. and YADAV, P.S., 2014. Effect of growth factor and antioxidant on in vitro maturation of oocytes and cleavage rates of in vitro produced Indian buffalo (Bubalus bubalis) embryos. Veterinarski Arhiv, vol. 84, pp. 459-474.

SHARMA, A., BADDELA, V.S., ROETTGEN, V., VERNUNFT, A., VIERGUTZ, T., DANNENBERGER, D., HAMMON, H.M., SCHOEN, J. and VANSELOW, J., 2020. Effects of dietary fatty acids on bovine oocyte competence and granulosa cells. Frontiers in Endocrinology, vol. 11, pp. 87. http://dx.doi.org/10.3389/ fendo.2020.00087. PMid:32158433.

STEELE, C.E.,JEFFERY, E.H. and DIPLOCK, A.T., 1974. The effect of vitamin E and synthetic antioxidants on the growth in vitro of explanted rat embryos. Journal of Reproduction and Fertility, vol. 38, no. 1, pp. 115-123. http://dx.doi.org/10.1530/jrf.0.0380115. PMid:4841385.

STURMEY, R.G., REIS, A., LEESE, H.J. and MCEVOY, T.G., 2009. Role of fatty acids in energy provision during oocyte maturation and early embryo development. Reproduction in Domestic Animals, vol. 44, pp. 50-58. https://doi.org/10.1111/j.14390531.2009.01402.x.

THIYAGARAJAN, B. and VALIVITTAN, K., 2009. Ameliorating effect of vitamin $\mathrm{E}$ on in vitro development of preimplantation buffalo embryos. Journal of Assisted Reproduction and Genetics, vol. 26, no. 4, pp. 217-225. http://dx.doi.org/10.1007/s10815-0099302-1. PMid:19252977.

VAN METRE, D.C. and CALLAN, R.J., 2001. Selenium and vitamin E. The Veterinary Clinics of North America. Food Animal Practice, vol. 17, no. 2, pp. 373-402, vii-viii. http://dx.doi.org/10.1016/ S0749-0720(15)30034-7. PMid:11515407.

WAGNER, B.A., BUETTNER, G.R. and BURNS, C.P., 1996. Vitamin E slows the rate of free radical-mediated lipid peroxidation in cells. Archives of Biochemistry and Biophysics, vol. 334, no. 2, pp. 261267. http://dx.doi.org/10.1006/abbi.1996.0454. PMid:8900400.

WANG, X., FALCONE, T., ATTARAN, M., GOLDBERG, J.M., AGARWAL, A. and SHARMA, R.K., 2002. Vitamin C and Vitamin E supplementation reduce oxidative stress-induced embryo toxicity and improve the blastocyst development rate. Fertility and Sterility, vol. 78, no. 6, pp. 1272-1277. http://dx.doi. org/10.1016/S0015-0282(02)04236-X. PMid:12477524. 